\title{
Prediksi luas kebakaran hutan dan lahan pada tahun 1997-2005 akibat faktor antropogenik menggunakan data CMIP5
}

\author{
Predicting burn area of forest and land fire 1997-2005 due to anthropogenic factors using CMIP5 \\ data \\ Lesi Mareta $^{\mathrm{a}}$, Arnida Lailatul Latifah ${ }^{\mathrm{b}}$, Rahmat Hidayat $^{\mathrm{c}}$, Rini Hidayati ${ }^{\mathrm{c}}$ \\ a Atmospheric and Planetary Sciences, Sumatera Institute of Technology, South Lampung, Lampung, 35365, Indonesia \\ ${ }^{\mathrm{b}}$ Laboratorium of High-Performance Computing, Research Center for Informatics, Indonesian Institute of Sciences, Bogor, West \\ Java, 16916, Indonesia \\ ${ }^{\mathrm{c}}$ Department of Geophysics and Meteorology, Bogor Agricultural University, Kampus IPB Darmaga Bogor, 16680, Indonesia
}

\section{Article Info:}

Received: 08 - 05 - 2021

Accepted: 25 - 06 - 2021

Keywords:

Antropogenic, CMIP5, karhutla, random forest

Corresponding Author:

Lesi Mareta

Program studi Sains Atmosfer

dan Keplanetan, Jurusan Sain,

Institut Teknologi Sumatera;

Tel. +6281546235049

Email:

Lesi.mareta@sap.itera.ac.id

\begin{abstract}
Forest and land fires are an annual local and national disaster that occurs in Indonesia. Two factors influence forest and land fires: natural forcing and/or anthropogenic forcing (human activity). Human activity releases large amounts of carbon dioxide $\left(\mathrm{CO}_{2}\right)$, carbon monoxide $(\mathrm{CO})$, methane $\left(\mathrm{CH}_{4}\right)$, oxidant rates, nitrogen dioxide (NOx), and particulates which act as sources of greenhouse warming that have been monitored by satellites in recent years. This study will examine the burn area of forest and land fires in recent decades due to anthropogenic factors in Kalimantan using two types of data, namely data without and with anthropogenic components. Analysis by utilizing output data from the CMIP5. This study uses a statistical approach to the technique of Random Forests $(R F)$ to evaluate the contribution of climate and anthropogenic factors to the extent of forest and land fires in the Kalimantan region. General conditions of forest and land fires are based on observational data obtained from GFED data. The two highest areas that occurred in Kalimantan during 1997 to 2005 occurred in 1997 and 2002. According to the three models in 1997 and 2002, anthropogenic factors had a more dominant influence on the extent of forest and land fires in Kalimantan. In 1997 and 2002, the area of forest and land fires affected by anthropogenic factors was positive, and anthropogenic factors contributed to increasing the forest and land fires extent.
\end{abstract}

How to cite (CSE Style $8^{\text {th }}$ Edition):

Mareta L, Latifah AL, Hidayat R, Hidayati R. 2021. Prediksi luas kebakaran hutan dan lahan pada tahun 1997-2005 akibat faktor antropogenik menggunakan data CMIP5. JPSL 11(2): 324-333. http://dx.doi.org/10.29244/jpsl.11.2.324-333.

\section{PENDAHULUAN}

Kebakaran hutan dan lahan (Karhutla) sudah menjadi bencana lokal dan nasional tahunan yang ada di Indonesia. Dampak kebakaran hutan dan lahan tidak hanya berpengaruh terhadap kualitas hidup utamanya kesehatan masyarakat, ekonomi dan sosial masyarakat secara nasional, namun dampaknya telah meluas menjadi bencana regional. Selain dampaknya terhadap kesehatan masyarakat dan ekonomi, karhutla juga dianggap sebagai ancaman potensial bagi pembangunan berkelanjutan karena efeknya dapat terjadi secara langsung bagi ekosistem, kontribusinya terhadap peningkatan emisi karbon dan dampaknya bagi keanekaragaman hayati (Mareta et al., 2019a). Karhutla dalam skala besar pernah terjadi di Indonesia pada 
tahun 1982-1983, 1991, 1994, 1997-1998, dan 2006. Kebakaran hutan dan lahan secara garis besar dipengaruhi oleh dua faktor, yaitu terjadi karena alami (Natural forcing) dan/atau ulah manusia (Anthropogenic forcing). Kebakaran yang terjadi akibat alam misalnya, karena petir, karena kemarau panjang, sehinggga matahari akan membakar tanaman yang kering melalui hal sederhana seperti adanya percikan api karena pembiasan cahaya dari kaca/kaleng yang mengkilap. Sedangkan kebakaran oleh manusia, misalnya hutan atau lahan sengaja di bakar karena ingin membuka hutan atau lahan. Pada paper ini yang dimaksud dengan faktor antropogenik adalah aktivitas manusia secara umum yang menghasilkan gas rumah kaca. Menurut (Lestari et al., 2015), Aktivitas manusia tersebut melepaskan sejumlah besar karbon dioksida $\left(\mathrm{CO}_{2}\right)$, karbon monoksida (CO), metana $\left(\mathrm{CH}_{4}\right)$, oksida nitrat, nitrogen dioksida (NOx) dan partikulat yang bertindak sebagai sumber pemanasan rumah kaca yang telah dipantau oleh satelit beberapa tahun terakhir, sehingga ini memudahkan untuk melihat pengaruh faktor antropogenik terhadap luas kebakaran hutan dan lahan.

Penelitian ini akan melihat luas daerah terbakar pada peristiwa kebakaran hutan dan lahan dalam beberapa dekade terakhir yang didorong oleh faktor antropogenik, menggunakan dua jenis data yaitu data tanpa dan dengan komponen antropogenik. Analisa data dan dengan komponen antropogenik dilakukan dengan memanfaatkan data Global Climate Model (GCM). Penggunaan data GCM untuk analisis karhutla telah di lakukan Lestari et al. pada tahun 2015 dan Mareta et al. pada tahun 2019a. Penelitian ini menggunakan pendekatan Random Forests (RF) untuk mengevaluasi kontribusi faktor antropogenik terhadap luas kebakaran hutan dan lahan di daerah Kalimantan. Random Forests (RF) adalah metode pembelajaran berdasarkan pohon klasifikasi dan regresi (CART) (Guo et al., 2016).

\section{METODE}

\section{Lokasi Penelitian}

Lokasi penilitian ini adalah Pulau Kalimantan, Indonesia. Kalimantan merupakan pulau di Indonesi yang rentan terjadi kebakaran hutan dan lahan. Pulau Borneo terletak di $8^{\circ} \mathrm{LU}$ hingga $5^{\circ} \mathrm{LS}$ dan $108^{\circ} \mathrm{BT}$ hingga $120^{\circ} \mathrm{BT}$.

\section{Metode Pengumpulan Data}

Data yang digunakan dalam penelitian adalah data iklim dan data indeks kebakaran hutan dan lahan di kalimantan.

\section{Data Iklim}

Data iklim untuk wilayah Kalimantan diperoleh dari data luaran model dari Coupled Model Intercomparison Project Phase 5 (CMIP5), Model CMIP5 yang digunakan dalam penelitian ini adalah model CSIRO MK-3.6 dengan resolusi spasial $1.8^{\circ}$ x 1.8 (Rotstayn et al., 2010) setara dengan (198 x 198) km, dan model ACCESS1.3 dengan resolusi spasial $1.25^{\circ}$ x $1.87^{\circ}$ (Collier dan Uhe, 2012) atau setara dengan (137.5 x 207.57) km. Model CMIP5 yang digunakan dalam penelitian ini adalah eksperimen data baseline (1997-2005), dengan variabel kelembaban relatif permukaan (Hurs), suhu udara permukaan (Tas), dan curah hujan. Pemilihan model luaran CMIP5 berdasarkan ketersediaan data variabel yang dibutuhkan (Lestari et al., 2015). Data iklim diunduh dari laman resmi CMIP5 (https://esgf-node.llnl.gov/ projects/cmip5/).

\section{Data Indeks Kebakaran Hutan dan Lahan di Kalimantan}

Data kebakaran hutan dan lahan di Kalimantan diperoleh dari data Global Fire Emissions Database (GFED). Kumpulan data ini memberikan perkiraan global area terbakar bulanan, emisi bulanan data memiliki resolusi spasial $0.25^{\circ} \times 0.25^{\circ}$ atau setara dengan $(27.75 \times 27.75) \mathrm{km}$. Data tersedia dari bulan Juli 1997 sampai 2014. Data luas karhutla (burn area) diunduh di laman resmi GFED (https://www.global firedata.org/). 


\section{Metode Analisis Data}

\section{Proses Pemodelan Luas Karhutla Menggunakan Random Forests}

Studi ini menggunakan pendekatan Random Forests (RF) untuk mengevaluasi kontribusi iklim dan antropogenik terhadap kebakaran hutan dan lahan di daerah Kalimantan. Random Forests (RF) adalah metode pembelajaran berdasarkan pohon klasifikasi dan regresi (Guo et al., 2016). Data observasi luas karhutla di Kalimantan yang diperoleh merupakan data luas karhutla yang dipengaruhi oleh faktor alam dan faktor antropogenik, sehingga data tersebut tidak dapat digunakan secara langsung untuk melihat luas karhutla yang dipengaruhi oleh faktor antropogenik. Luas karhutla yang dipengaruhi oleh faktor antropogenik diperoleh dari selisih luas karhutla yang dipengaruhi oleh faktor alam dan faktor antropogenik serta luas karhutla yang dipengaruhi oleh faktor alam saja. Oleh karena itu, dibutuhkan suatu teknik statistik untuk membangun model luas karhutla yang dipengaruhi oleh faktor alam dan faktor antropogenik serta luas karhutla yang dipengaruhi oleh faktor alam saja.

Kontribusi faktor alam dianalisis dengan menggunakan teknik statistik Random Forests. Pada penelitian ini, teknik statistik Random Forests memanfaatkan meachine learning dengan perintah sebagai berikut:

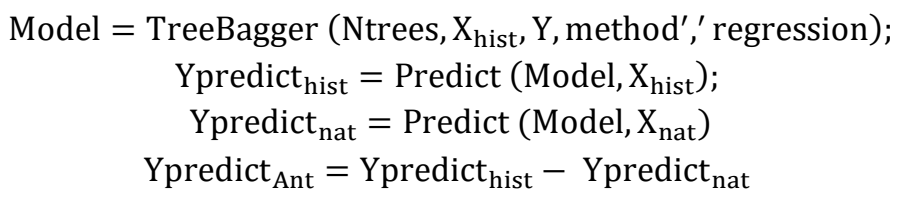

Model adalah luas karhutla yang dihasilkan melalui teknik random forest, Ypredict_hist adalah model luas karhutla historis, merupakan campuran antara pengaruh faktor alam dan faktor antropogenik. Ypredict_nat adalah model luas karhutla yang dipengaruhi oleh faktor alam, Xhist adalah data iklim yang dipengaruhi oleh faktor alam dan faktor antropogenik, Xnat adalah data iklim yang dipengaruhi oleh faktor alam, Y adalah data observasi luas karhutla. Xhist dan Xnat diperoleh dari luaran model CMIP5. Ypredict ${ }_{\text {Ant }}$ adalah luas karhutla yang dipengaruhi oleh faktor antropogenik, Ypredict_hist adalah model luas karhutla historis, Ypredict_nat adalah model luas karhutla yang dipengaruhi oleh faktor alam.

\section{HASIL DAN PEMBAHASAN}

\section{Kondisi Umum Luas Karhutla di Kalimantan}

Menurut peraturan menteri kehutanan nomor: P.12/Menhut-II/2009, kebakaran hutan dan lahan adalah suatu keadaan dimana hutan dan lahan dilanda api, sehingga mengakibatkan kerusakan hutan dan lahan yang menimbulakan kerugian ekonomis dan atau nilai lingkungan. Kondisi umum luas karhutla adalah kondisi luas daerah terbakar hutan dan lahan yang dipengaruhi oleh faktor alam dan antropogenik. Kebakaran hutan menjadi perhatian internasional sebagai isu lingkungan dan ekonomi, kgusunya setelah bencana ENSO 1997/98 yang menghanguskan lahan hutan seluas 25 juta hektar di seluruh dunia. Selama peristiwa ENSO 1997/98, Indonesia mengalami kebakaran hutan yang paling hebat di dunia. Masalah yang terulang pada tahun 2002 (Tacconi, 2003). Wahana Lingkungan Hidup (WALHI) menyatakan 13 juta hektar hutan dan lahan di Indonesia terdampak oleh karhutla sedangkan menurut Badan Perencanaan Pembangunan Nasional (BAPPENAS) bersama ADB mengistimimasi 9.75 juta hektar (Hunawan, 2016).

Berdasarkan data observasi yang diperoleh dari data GFED khusus data burn area, luas karhutla dua tertinggi yang terjadi di Kalimantan selama periode 1997 hingga 2005 terjadi pada tahun 1997 dan 2002. Pada tahun 1997 dan 2002 di Indonesia terjadi fenomena ENSO yang berasosiasi dari samudera pasifik. ENSO adalah sebuah fenomena perubahan perbedaan temperatur di daerah tropikal di timur Samudra Pasifik (Pulau Tahiti) dan barat Samudera Pasifik (Darwin, Australia) (Mareta et al., 2019b). Fenomena ENSO akan memengaruhi klimatologi curah hujan di Indonesia. Pada tahun 1997 dan 2002 El Niño kuat yang 
menyebabkan Indonesia mengalami defisit curah hujan yang signifikan, sehingga pada tahun tersebut mengalami kekeringan dan hal inilah yang menjadi pemicu terjadi karhutla.

Model luas karhutla berdasarkan luaran model ACCESS1.3 dan CSIRO-mk3.6.0 dan data observasi menunjukkan bahwa luas karhutla dua tertinggi pada periode dari tahun 1997 hingga 2005 terjadi pada tahun 1997/98 dan tahun 2002. Data model luas karhutla terhadap data observasi memiliki pola yang sama tetapi dengan besar luas daerah terbakar sangat berbeda. Pada Gambar 1, luas Karhutla pada tahun terjadinya fenomena ENSO, seperti pada tahun 1997/98, 1999/00, 2002, dan 2004 data model luas karhutla lebih kecil dibandingkan dengan data observasi.
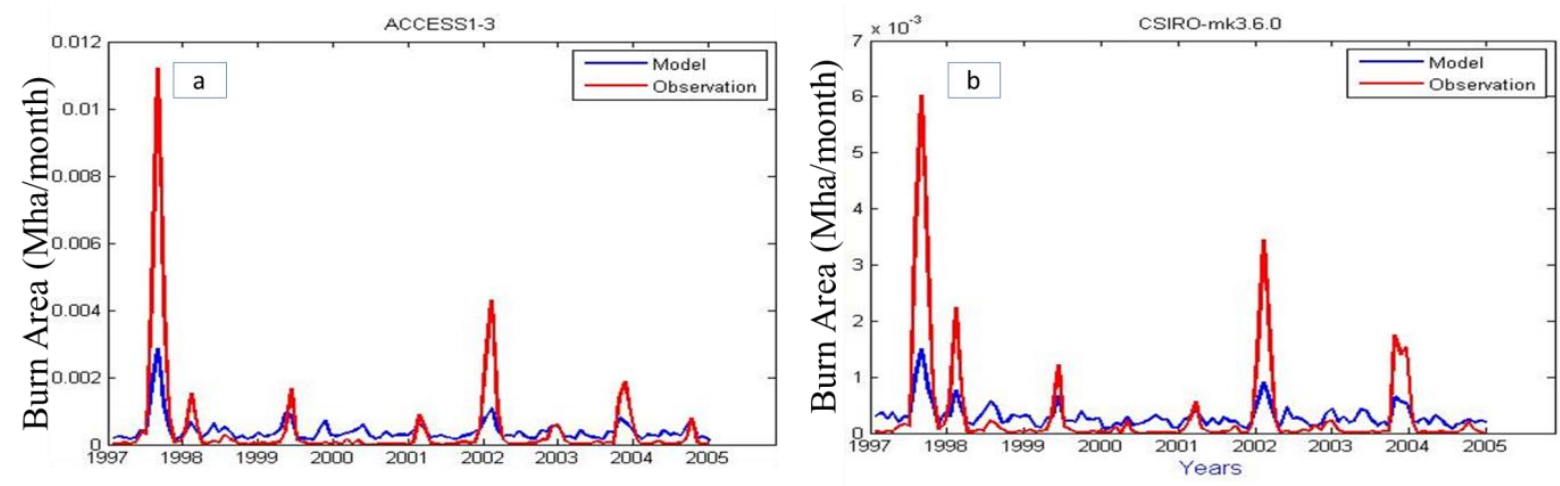

Gambar 1 Luas kebakaran hutan dan lahan berdasarkan data GFED (merah) dan data model (biru): (a) ACCESS1-3; (b) CSIRO-mk3.6.0

Pola model luas karhutla ketika tidak terjadi fenomena ENSO, variabel iklim (suhu udara permukaan, kelembaban relatif permukaan, dan curah hujan) tetap terekam oleh model ACCESS1.3 dan CSIRO-mk3.6.0 yang kemudian dibangun menjadi luas karhutla, hal inilah yang menyebabkan pada tahun tidak terjadi fenomena ENSO model luas karhutla tetap ada (terhitung), sehingga luas karhutla berdasarkan data model lebih tinggi dibandingkan dengan data observasi. Data observasi luas karhutla menggambarkan luas karhutla mendekati kondisi nyata, sehingga ketika tidak terjadi karhutla maka data observasi luas karhutla mendekati nol. Luas karhutla berdasarkan luaran model ACCESS1.3 dan perbandingan dengan data observasi ditunjukkan oleh Gambar 1a.

Model luas karhutla luaran CSIRO-MK3.6.0 pada Gambar 1b menunjukkan bahwa model luas karhutla empat tertinggi pada periode dari tahun 1997 hingga 2005 adalah tahun 1997 dan tahun 2002. Tahun 1997/1998 Indonesia mengalami fenomena El Niño kuat, tahun 2002 Indonesia mengalami El Niño sedang (moderat), dan pada tahun 2004 Indonesia mengalami El Niño lemah, sehingga Indonesia khususnya di Kalimantan mengalami penurunan curah hujan dan mengalami musim kering yang panjang menyebabkan karhutla semakin meluas.

\section{Pengaruh Antropogenik Terhadap Luas Karhutla di Kalimantan}

Karhutla dapat dipengaruhi oleh faktor alam dan/atau faktor antropogenik. Pengaruh antropogenik dapat dilihat dari pola rata-rata bulanan luas karhutla dan distribusi spasial luas karhutla. Pengaruh faktor antropogenik diperoleh dari selisih semua faktor (faktor alam dan faktor antropogenik) dengan faktor alam. Faktor alam diantaranya adalah fenomena alam El Niño. Selama periode 1997 hingga 2005, El Niño 1997 1998 tercatat memiliki curah hujan paling rendah di Indonesia menyebabkan kondisi karhutla yang meluas (Byron dan Shepherd, 1998). Menurut Siegert dan Hoffmann (1998) karhutla di Kalimantan didorong kuat oleh fenomena El Niño. El Niño yang kuat pada 1997/1998 menyebabkan kondisi kekeringan parah, sehingga kebakaran pembukaan lahan menjadi tidak terkendali khususnya di Kalimantan dan Sumatera (Langmann dan Heil, 2004). 
Luas karhutla diperoleh dari data GFED yang selanjutnya disebut data observasi luas karhutla merupakan data luas karhutla yang dipengaruhi oleh semua faktor (faktor alam dan faktor antropogenik), untuk melihat pengaruh antropogenik perlu dilakukan pemisahan luas karhutla yang dipengaruhi oleh semua faktor, faktor alam, dan faktor antopogenik. Data observasi luas karhutla tidak dapat dipisahkan, maka diperlukan suatu model luas karhutla yang dapat dipisahkan.

Luaran model CMIP5 menyediakan data iklim yang dipengaruhi oleh semua faktor (historical) dan faktor alam (historicalNAT). Menurut Guo et al. (2016) data iklim dapat digunakan untuk menghasilkan luas karhutla model dengan menggunakan teknik random forests. Model luas karhutla hasil teknik random forest yang memanfaatkan luaran CMIP5 merupakan model luas karhutla yang dipengaruhi oleh semua faktor dan luas karhutla yang dipengaruhi oleh faktor alam, sehingga model luas karhutla hasil random forests dapat dimanfaatkan untuk melihat pengaruh faktor antropogenik terhadap luas karhutla.

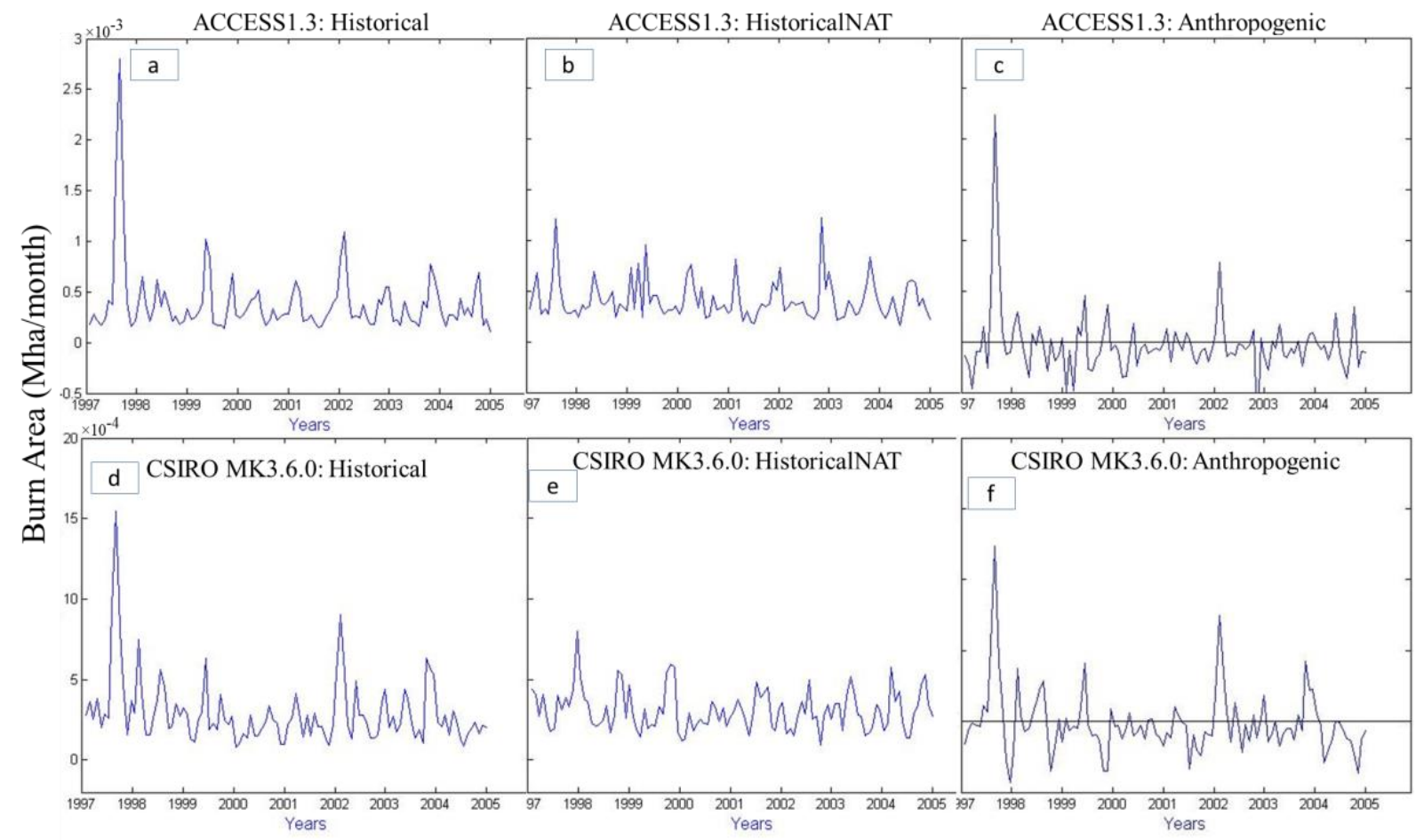

Gambar 2 Distribusi temporal luas karhutla di Kalimantan berdasarkan Model ACCESS1.3 [(a) historis, (b) alam, (c) antropogenik] dan CSIRO MK3.6.0 [(d) historis, (e) alam, (f) antropogenik]

Menurut model ACCESS1.3 (Gambar 2a, 2b dan 2c) pada tahun 1997 dan 2002 terlihat bahwa faktor antropogenik memberikan pengaruh positif (bernilai negatif) terhadap luas karhutla di Kalimantan artinya faktor antropogenik pada tahun 1997 dan 2002 menyebabkan luas karhutla meningkat. Pada tahun 1999 dan 2003, menurut model ACCESS1.3 faktor antropogenik memberikan pengaruh positif (bernilai negatif), hal ini disebabkan oleh adanya beberapa gas-gas serta partikulat yang dihasilkan oleh aktivitas antropogenik memiliki sifat dapat menurunkan suhu udara, diantaranya aerosol sulfat, nitrat dan debu.

Sementara faktor alam sepanjang tahun 1997 hingga 2005 bernilai positif, artinya faktor alam sepanjang tahun 1997 hingga 2005 menjadi pendukung terjadinya karhutla. Pola model luas karhutla akibat pengaruh faktor alam (Gambar 2b) mengikuti pola kejadian ENSO. Luas karhutla akibat pengaruh faktor alam tinggi pada tahun 1997, 2002/2003. Pada tahun 1997 dan 2002/2003 terjadi El Niño kuat dan El Niño sedang. Luas karhutla tinggi yaitu pada tahun 1997 dan 2002 faktor alam tidak dominan jika dibandingkan dengan pengaruh faktor antropogenik. Saat kondisi El Niño tahun 2004, curah hujan di Kalimantan Barat cukup rendah terutama di bulan Agustus yang mencapai 58 mm (Anggraini dan Trisakti, 2009). 
Menurut model CSIRO-MK3.6.0 (Gambar 2d, 2e dan 2f) luas karhutla tinggi terjadi pada tahun 1997 dan 2002, faktor antropogenik memberikan pengaruh negatif lebih dominan dibandingkan dengan faktor alam. Pada tahun 1997 dan 2002 luas karhutla akibat pengaruh antropogenik bernilai positif (menyebabkan luas karhutla meningkat). Pengaruh faktor alam pada periode tahun 1997 hingga 2005 konsisten bernilai positif.

\section{Distribusi Spasial Historis (Historical) Luas Karhutla di Kalimantan}

Luas karhutla historis adalah luas karhutla yang dipengaruhi oleh faktor alam dan faktor antropogenik. Spasial observasi luas kebakaran hutan dan lahan di Kalimantan pada periode 1997 sampai 2005 dapat dilihat pada Gambar 3. Luas kebakaran hutan dan lahan di Kalimantan mulai mengalami peningkatan pada bulan Juli, mencapai luas daerah terbakar tertinggi pada bulan September, dan pada bulan Oktober luas kebakaran hutan dan lahan di Kalimantan mulai menurun. Peningkatan luas kebakaran hutan dan lahan di Kalimantan yang terjadi pada bulan Juli, peningkatan luas kebakaran hutan dan lahan di mulai di daerah Kalimantan Selatan, dan pada bulan Agustus kebakaran hutan dan lahan mulai meluas ke sebagian Kalimantan Tengah dan Kalimantan Barat.

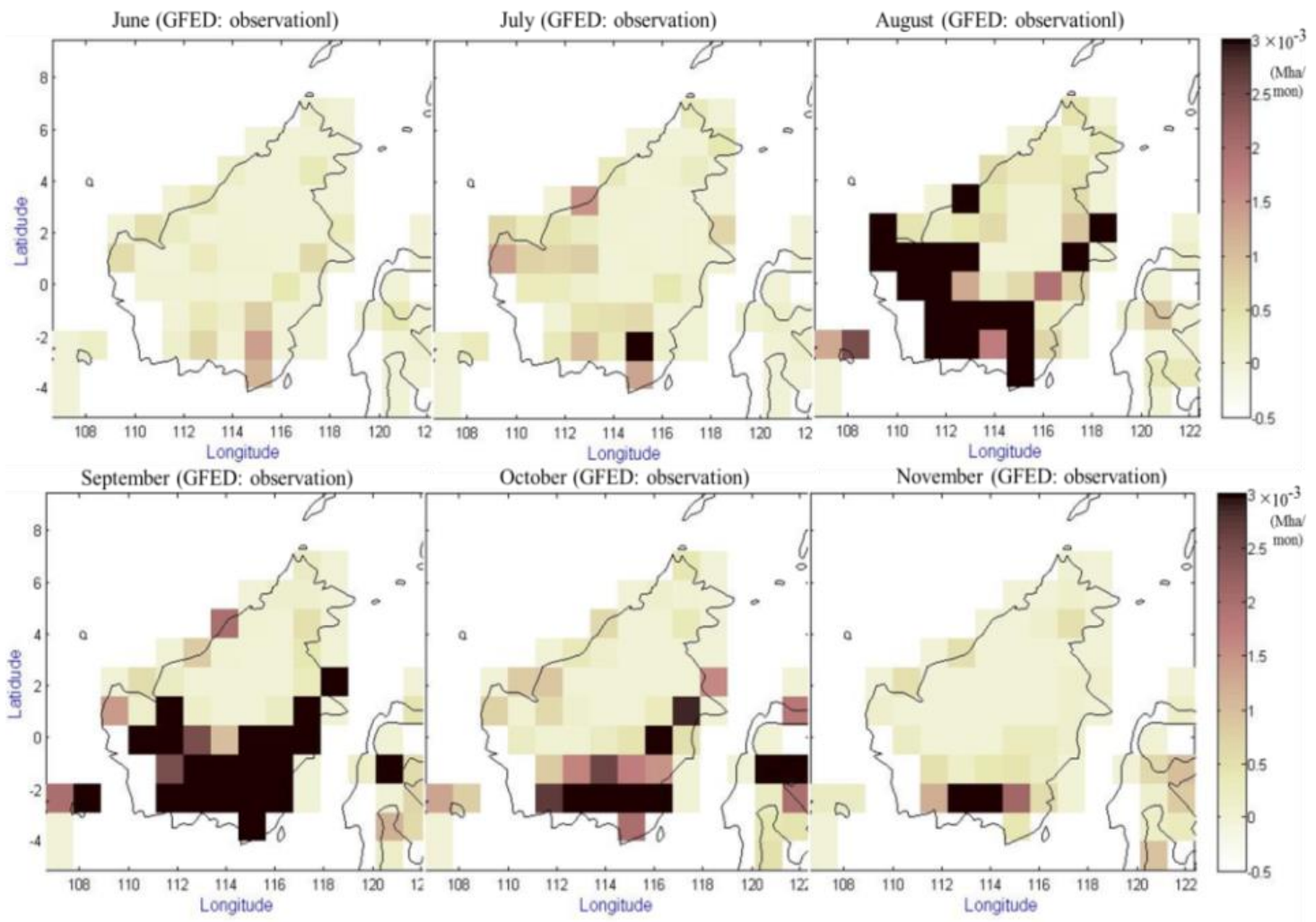

Gambar 3 Distribusi spasial historis luas karhutla di Kalimantan berdasarkan data GFED (Mha/bulan)

Luas kebakaran hutan dan lahan pada bulan September semakin meningkat. Pada bulan Agustus area luas kebakaran hutan dan lahan yang tinggi terjadi pada sebagian Kalimantan Selatan, Kalimantan Tengah dan Kalimantan Barat. Sementara, pada bulan September area terbakar di Kalimantan Selatan, Kalimantan Tengah, Kalimantan Barat yang telah tinggi pada bulan Agustus akan semakin meningkat dan merambat ke Kalimantan Timur. Menurut (Siegert dan Hoffmann,1998) kondisi cuaca kering yang diciptakan oleh fenomena El Niño di Kalimantan Timur berlangsung hingga Mei 1998. Tidak ada curah hujan yang signifikan tercatat di Samarinda dan Balikpapan dari Januari hingga akhir April, sedangkan semua provinsi lain di Kalimantan dan Sumatera dan bagian utara Kalimantan Timur dan mengalami curah hujan normal hingga deras pada awal Maret. Pada 1997/1998, Indonesia mengalami bencana kebakaran terbesar dalam sejarahnya sendiri dan global, salah satu dampaknya adalah menyebabkan di Kalimantan Timur daerah terbakar sekitar adalah 5.2 juta hektar. 
Luas kebakaran hutan dan lahan di sebagian area Kalimantan Barat pada bulan Oktober mulai menurun, dan pada bulan Oktober area yang terbakar hanya terfokus di sebagian daerah Kalimantan Tengah, Kalimantan Selatan dan Kalimantan Timur. Sementara pada bulan November, luas kebakaran hutan dan lahan mulai menurun. Kalimantan Timur, Kalimantan Selatan, dan Kalimantan Barat pada bulan November tidak ada lagi area yang terbakar, walaupun ada tetapi tidak lebih luas dibandingkan dengan Kalimantan Tengah, sedangkan di sebagian Kalimantan Tengah masih terdapat area yang terbakar.
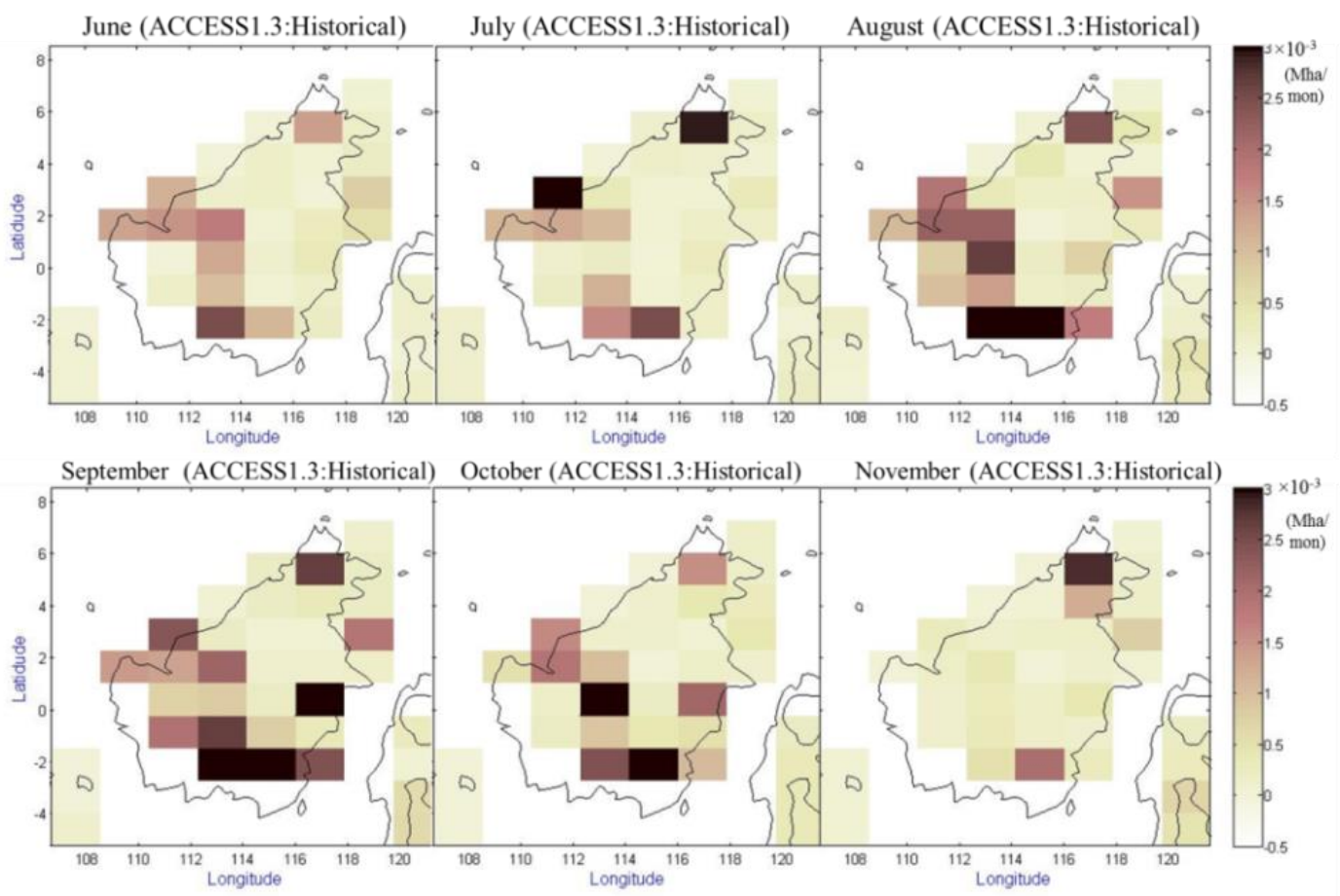

Gambar 4 Distribusi spasial historis luas karhutla di Kalimantan berdasarkan Model ACCESS1.3

(Mha/bulan)
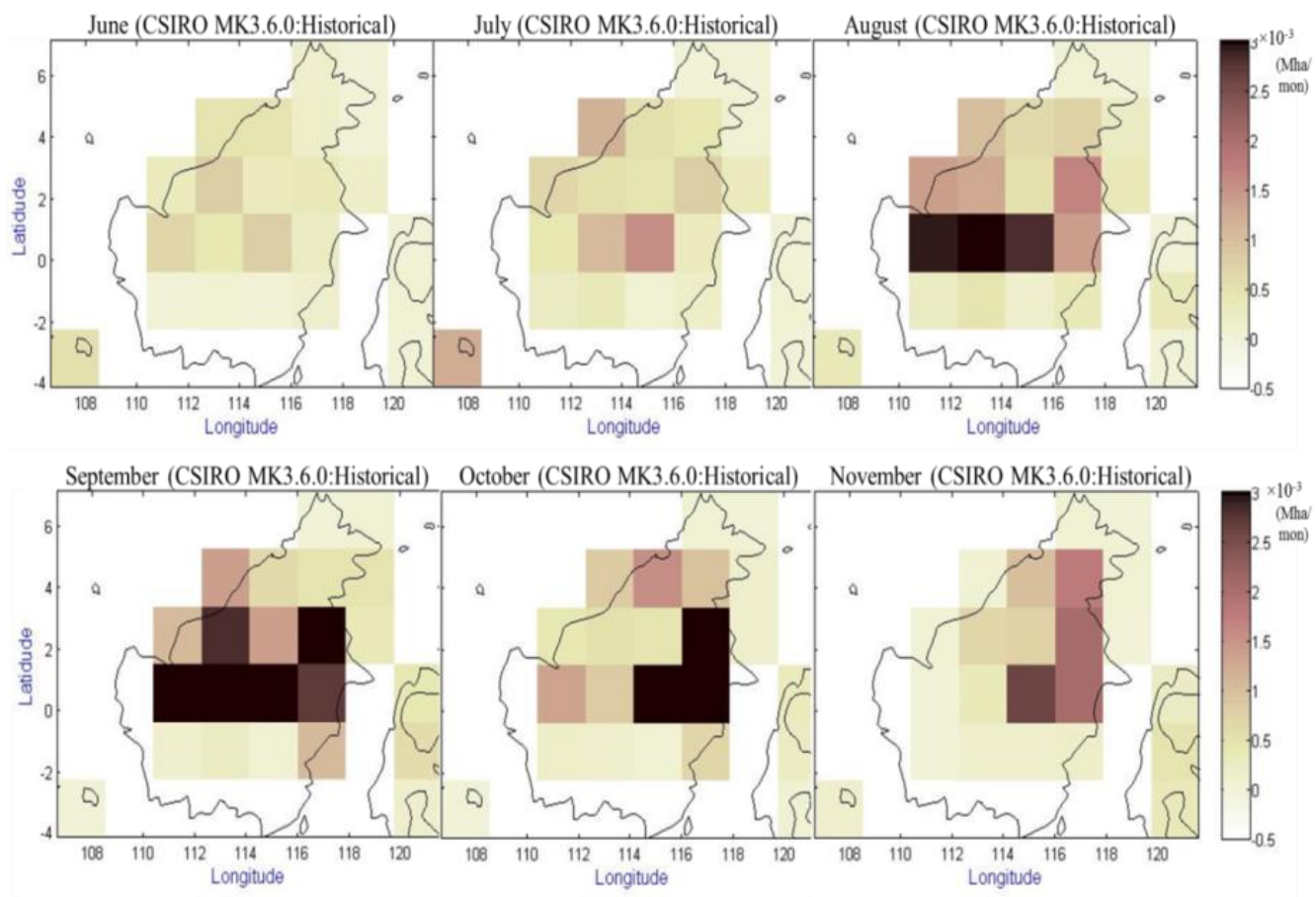

Gambar 5 Distribusi spasial historis luas karhutla di Kalimantan berdasarkan Model CSIRO MK3.6.0 (Mha/bulan) 
Luas kebakaran hutan dan lahan di Kalimantan selama periode 1997 hingga 2005 berdasarkan model ACCESS1.3 dengan resolusi spasial $1.25^{\circ} \times 1.87^{\circ}$ pada bulan Juli mulai mengalami peningkatan di Kalimantan Tengah, dan pada bulan Agustus luas karhutla mengalami ekspansi ke Kalimantan Barat dan Kalimantan Selatan, ekspansi tersebut bertahan hingga bulan September. Pada bulan Oktober luas kebakaran hutan dan lahan mulai menurun. Luas kebakaran hutan dan lahan di Kalimantan selama periode 1997 hingga 2005 berdasarkan model ACCESS1.3 dapat dilihat pada Gambar 4.

Model CSIRO-MK3.6.0 dengan resolusi spasial $1.8^{\circ}$ x $1.8^{\circ}$ menggambar pola spasial luas kebakaran hutan dan lahan di Kalimantan bahwa selama periode 1997-2005. Gambar 5 menjelaskan bahwa luas kebakaran hutan dan lahan di Kalimantan mulai terjadi peningkatan pada bulan Juli di daerah Kalimantan Tengah dan Kalimantan Timur. Pada bulan Agustus luas kebakaran hutan dan lahan mengalami ekspansi ke arah Kalimantan Barat, dan pada bulan September luas kebakaran hutan dan lahan mencapai area terbakar tertinggi, sementara pada bulan Oktober daerah Kalimantan Timur menjadi area yang mempunyai luas kebakaran hutan dan lahan tertinggi.

\section{Distribusi Spasial Luas Karhutla Akibat Pengaruh Antropogenik}

Pengaruh antropogenik terhadap luas karhutla di Kalimantan selama periode 1997 hingga 2005 diperoleh dari selisih antara luas kebakaran hutan dan lahan di Kalimantan yang dipengaruhi oleh semua faktor dengan luas kebakaran hutan dan lahan di Kalimantan yang dipengaruhi oleh faktor alam.

Model ACCESS1.3 menggambarkan bahwa pola distribusi spasial kebakaran hutan dan lahan di Kalimantan yang dipengaruhi oleh faktor antropogenik mulai terlihat tinggi pada bulan Agustus. Pada bulan Agustus area yang terbakar terjadi di daerah Kalimantan Barat, Kalimantan Selatan dan Kalimantan Tengah. Pada bulan September area yang terbakar semakin meningkat, yakni di Kalimantan Timur. Sementara pada bulan Oktober, luas kebakaran hutan dan lahan yang dipengaruhi oleh faktor antropogenik mulai menurun dan area terbakar hanya terlihat di sebagian daerah Kalimantan Selatan dan Kalimantan Timur, sedangkan pada bulan November area terbakar di Kalimantan tidak ada. Pola distribusi luas karhutla yang dipengaruhi oleh faktor antropogenik menurut model ACCESS1.3 dapat dilihat pada Gambar 6.
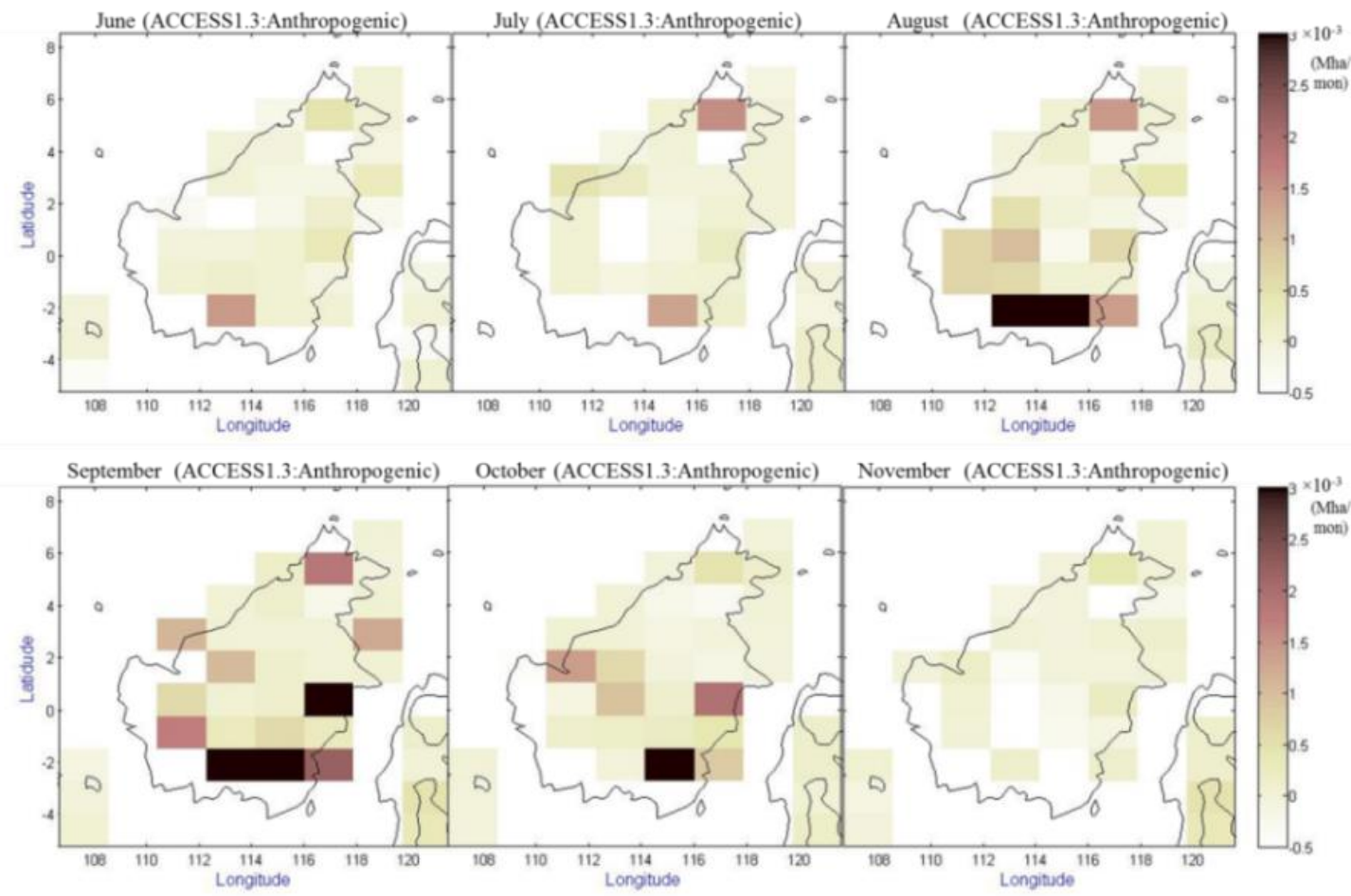

Gambar 1 Distribusi spasial antropogenik luas karhutla di Kalimantan berdasarkan Model ACCEESS 1.3 (Mha/bulan). 
Luas karhutla di Kalimantan yang dipengaruhi oleh faktor antropogenik menurut model CSIRO-MK3.6.0 (Gambar 7) mulai mengalami peningkatan pada bulan Juli. Pada bulan Juli, luas kebakaran hutan dan lahan yang dipengaruhi oleh faktor antropogenik terdapat di sebagian daerah Kalimantan Tengah. Area terbakar yang terdapat di daerah sebagian Kalimantan Tengah mengalami ekspansi ke arah Kalimantan Timur pada bulan Agustus. Pada bulan September area yang terbakar di Kalimantan semakin luas yakni di Kalimantan Barat dan Kalimantan Selatan. Sementara, pada bulan Oktober area terbakar hanya terdapat di Kalimantan Timur.
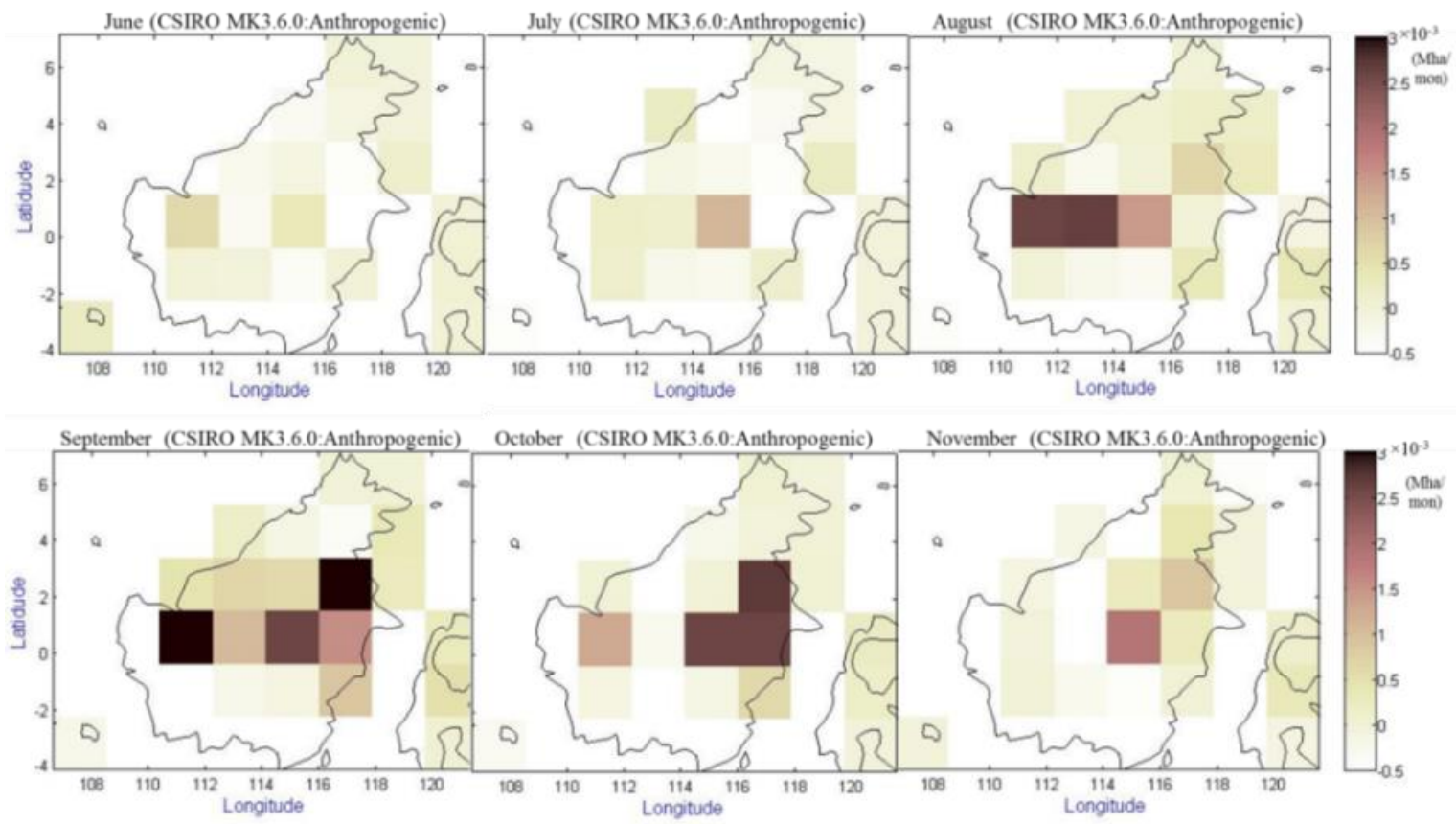

Gambar 7 Distribusi spasial antropogenik luas karhutla di Kalimantan berdasarkan Model CSIRO MK3.6.0 (Mha/bulan)

\section{KESIMPULAN}

Luaran kedua model dan data observasi menunjukkan konsistensi luas tertinggi karhutla pada periode 1997 hingga 2005 terjadi tahun 1997 dan 2002. Menurut model ACCESS1.3 dan CSRIRO-MK3.6.0 pada tahun 1997 dan 2002, terlihat bahwa faktor antropogenik memberikan pengaruh lebih dominan terhadap luas karhutla di Kalimantan. Pengaruh faktor alam selalu bernilai positif sepanjang tahun 1997 hingga 2005, artinya selama periode 1997 hingga 2005, pengaruh faktor alam mendukung atau sebagai pemicu terjadinya karhutla.

Model CSIRO-MK3.6.0 dan ACCESS1.3 dapat merepresentasikan luas karhutla di Kalimantan yang dipengaruhi oleh faktor antropogenik. Faktor antropogenik yang dimaksud adalah semua kegiatan manusia yang menghasilkan gas-gas rumah kaca. Pada tahun 1997 dan 2002, luas karhutla oleh faktor antropogenik sangat tinggi, hal ini dikarenakan pada tahun tersebut gas-gas rumah kaca sangat tinggi karena terjadi kebakaran hutan dan lahan. Kedua model memiliki resolusi spasial yang berbeda. Resolusi spasial sangat memengaruhi pola spasial sebuah model. Semakin tinggi resolusi spasial suatu model maka semakin baik model tersebut merepresetasikan data. Model CSIRO-MK3.6.0 memiliki resolusi spasial lebih rendah dibandingkan dengan model ACCESS1.3, artinya model ACCESS1.3 lebih baik dalam merepresentasikan data spasial luas karhutla dibandingkan dengan model CSIRO-MK3.6.0.

\section{UCAPAN TERIMA KASIH}

Ucapan terima kasih kepada program GBU45 (Guru Besar Under 45 tahun) ITERA (Institut Teknologi Sumatera). 


\section{DAFTAR PUSTAKA}

[Kemenhut] Kementerian Kehutanan. 2009. Peraturan Menteri Kehutanan Nomor: P.12/Menhuut-II/2009 tentang Pengendalian Kebakaran Hutan. Jakarta (ID): Kemenhut.

Anggraini N, Trisakti B. 2009. Kajian dampak perubahan iklim terhadap di Provinsi Kalimantan Barat. $J$ Penginderaan Jauh. 8: 11-20.

Byron N, Shepherd G. 1998. Indonesia and the 1997-98 el niño: Fire problems and long-term solutions. Natural Resources Perspectives. London (GB): Overseas Development Institute.

Collier M, Uhe P. 2012. CMIP5 Datasets From The ACCESS1.0 And ACCESS1.3 Coupled Climate Models. Melbourne (AU): The Centre for Australian Weather and Climate Research (a partnership between CSIRO and the Bureau of Meteorology)

Guo F, Zhang L, Jin S, Tigabu M, Su Z, Wang W. 2016. Modeling anthropogenic fire occurrence in the boreal forest of China using logistic regression and random forests. J Forest. 7(11): 1-14. doi: 10.3390/f7110250.

Hunawan D. 2016. Menyelesaikan kebakaran hutan dan lahan (karhutla) di Indonesia melalui "jalan pantas" atau "jalan pintas"?. J Univ Negeri Semarang. 2(1): 277-292.

Langmann B, Heil A. 2004. Release and dispersion of vegetation and peat fire emissions in the atmosphere over Indonesia 1997/1998. Atmos Chem Phys. 4: 2145-2160.

Lestari RK, Watanabe M, Imada Y, Shiogama H, Field RD, Takemura T, Kimoto M. 2015. Increasing potential of biomass burning over Sumatera, Indonesia induced by anthropogenic tropical warming. IOP Publishing Environ Res Lett. 9: 1-7.

Mareta L, Hidayat R, Hidayati R, Alsepan G. 2019b. Influence of the positive Indian Ocean Dipole in 2012 and El Niño-southern oscillation (ENSO) in 2015 on the Indonesian rainfall. IOP Conf Ser Earth Environ Sci. 284: 1-12. doi: 10.1088/1755-1315/284/1/012018.

Mareta L, Hidayat R, Hidayati R, Latifah AL. 2019a. Pengaruh faktor alami dan antropogenik terhadap luas kebakaran hutan dan lahan di Kalimantan. J Tanah dan Iklim. 48(2): 143-151.

Rotstayn LD, Collier MA, Dix MR, Feng Y, Gordon HB, O’Farrell SP, Smith IN, Syktus J. 2010. Improved simulation of Australian climate and ENSO-related rainfall variability in a global climate model with an interactive aerosol treatment. Int J Climatol. 30(7): 1067-1088. doi: 10.1002/joc.1952.

Siegert F, Hoffmann AA. 1998. The 1998 forest fires in East Kalimantan (Indonesia): A quantitative evaluation using high resolution, multitemporal ERS-2 SAR images and NOAA-AVHRR hotspot data. Remote Sens Environ. 72: 64-77.

Tacconi L. 2003. Kebakaran Hutan di Indonesia: Penyebab, Biaya dan Implikasi Kebijakan. Bogor (ID): CIFOR. 